\title{
A new mixture ratio of heparin for the cell salvage device
}

\author{
Eunsu Choi, and Wonsik Ahn \\ Department of Anesthesiology and Pain Medicine, Seoul National University Hospital, Seoul, Korea
}

Adequate cell salvage for extracorporeal circulation requires anticoagulants such as heparin. The guideline of the American Association of Blood Banks recommends that $1 \mathrm{~L}$ of $0.9 \%$ saline containing 30,000 units of heparin should be mixed with aspirated blood at a ratio of $15 \mathrm{ml}$ per $100 \mathrm{ml}$ of collected blood [1]. If we maintain the ratio of heparinized saline to blood at $15: 100$, we need 2 vials of the Korean heparin product because its maximum amount of heparin in a vial is 25,000 units [2]. Therefore, we developed an alternative method of anticoagulation using only 1 vial of heparin.

For extracorporeal circulation, the dose of heparin, which maintains an ACT of longer than $400-450$ seconds, is $300-400$ $\mathrm{U} / \mathrm{kg}$ body weight [3]. To simplify calculation, we assume blood volume to be $70 \mathrm{ml} / \mathrm{kg}$ because the average blood volume of men is $75 \mathrm{ml} / \mathrm{kg}$ and that of women is $65 \mathrm{ml} / \mathrm{kg}$. Since $70 \mathrm{ml}$ of blood requires 300 units of heparin, $100 \mathrm{ml}$ of blood requires 428 units of heparin. According to the guideline, $15 \mathrm{ml}$ of heparinized saline contains 450 units of heparin because $1 \mathrm{~L}$ of heparinzed saline contains 30,000 units of heparin. If we mix 25,000 units of heparin with $1 \mathrm{~L}$ of $0.9 \%$ saline, we need $18 \mathrm{ml}$ of heparinized saline to maintain the same amount of heparin because the new concentration of heparin is 25 units $/ \mathrm{ml}$. If we apply this method to a continuous autotransfusion system $\left(\mathrm{CATS}^{\circledR}\right.$ ), we should set the infusion rate at 234 drops per minute because 13 drops make $1 \mathrm{ml}$ in the CATS.

In summary, we can use 1 vial of heparin (25,000 units) to prevent coagulation in the cell salvage device using our mixture ratio.

\section{References}

1. Walters J, Shander A. Perioperative Blood Management: A Physicians Handbook. 2nd ed. Bethesda, American Association of Blood Banks. 2009, pp 67-9.

2. Korea Food and Drug Administration. Open information/Product information/heparin [Category number: 333]. Available from http://ezdrug.kfda.go.kr/kfda2.

3. Despotis GJ, Gravlee G, Filos K, Levy J. Anticoagulation monitoring during cardiac surgery: a review of current and emerging techniques. Anesthesiology 1999; 91: 1122-51.

Corresponding author: Wonsik Ahn, M.D., Department of Anesthesiology and Pain Medicine, Seoul National University Hospital, 28, Yeongeondong, Jongno-gu, Seoul 110-744, Korea. Tel: 82-2-2072-3087, Fax: 82-2-766-3087, E-mail: aws@snu.ac.kr This research was supported by a grant 09142KFDA466 from Korea Food \& Drug Administration in 2009.

(c) This is an open-access article distributed under the terms of the Creative Commons Attribution Non-Commercial License (http:// creativecommons.org/licenses/by-nc/3.0/), which permits unrestricted non-commercial use, distribution, and reproduction in any medium, provided the original work is properly cited. 